\title{
Analysis of Student Learning Difficulties in the Material of Digestive Systems in Sibolga City High Schools
}

\author{
Rahmad Agus Sinaga ${ }^{1}$, Melva Silitonga ${ }^{2 *}$, Martina Restuati $^{2}$ \\ ${ }^{I}$ Student of Postgraduate Biology Education, State University of Medan, Medan, Indonesia \\ ${ }^{2}$ Lecturer of Postgraduate Biology Education, State University of Medan, Medan, Indonesia
}

*Corresponding Author: Melva Silitonga, Lecturer of Postgraduate Biology Education, State University of Medan, Medan, Indonesia

\begin{abstract}
This study aims to determine the learning difficulties of high school students in the high school science class in Sibolga in the digestive system material, to know the students 'learning difficulties in the digestive system material, to know internal factors and external factors that affect students' learning difficulties in the digestive system material, to know the level of thinking ability critical students. This research is a qualitative descriptive research that is describing and explaining data based on the existence of reality in the field. This research is also called non-experimental research because in this study, researchers did not control and manipulate the research variables. The results showed that the learning outcomes of high school students throughout Sibolga City in human digestive system material were in the low category. Students in SHigh School in Sibolga City have learning difficulties. The lowest indicator is in teacher quality indicators with an average of $54.5 \%$ with moderate criteria.
\end{abstract}

Keywords: Difficulties Learning, Students

\section{INTRODUCTION}

Learning difficulties are the inability of a person to accept, understand and master learning material. Learning difficulties are a condition where students cannot learn naturally, due to threats, obstacles or disturbances in learning (Djamarah, 2011). These obstacles may be realized may also not be realized by the people who experience them, and are sociological, psychological, and physiological, and also the instruments and learning environment. Learning difficulties are one of the problems that require special attention. In India approximately 90 thousand people experience learning difficulties and an average of five people per class there are students who experience difficulties and even learning disabilities [1]. Indonesia also includes countries where students still experience learning difficulties. This can be seen from the PISA assessment in recent years. From the results of the 2015 PISA tests and evaluations the performance of Indonesian students is still relatively low. The average scores of Indonesian students' achievement for science, reading, and mathematics were ranked 62, 61, and 63 of the 69 countries evaluated. The ratings and average Indonesian scores did not differ greatly from the results of the 2012 PISA test and survey which were also in the low mastery material group. Based on the average value, there is an increase in the Indonesian PISA Value in the three competencies tested. The biggest increase was seen in science competencies, from 382 points in 2012 to 403 points in 2015. Reading competency has not shown a significant increase, from 396 in 2012 to 397 points in 2015.

The increase raised Indonesia's position 6 ranked upwards when compared to the second rank below in 2012. Whereas based on the median, the reading achievement of Indonesian students increased from 337 points in 2012 to 350 points in 2015. The higher median achievement of the mean is good indicators in terms of increasing access and quality equality inclusive [2].

From the PISA results it can be concluded that Indonesia is still ranked lower. The low level of achievement may be due to several things, such as the weak understanding of science by Indonesian students, which may be due to students still having difficulty learning in science, as well as in the field of natural science. This situation must be handled because it will have an impact on student learning outcomes. To handle it first must be analyzed the causes. 
Studying the material of Archaebacteria and Eubacteria students experience difficulties in understanding terminology, understanding concepts, and writing scientific names (Hidayatussaadah et al, 2016). Pontianak State 14 Middle School students still have difficulty learning in human digestive system material. Furthermore, it was explained that the factors that most influence the learning difficulties of students in Pontianak Pontianak State Middle School are internal factors on health indicators and external factors, namely media indicators [3]. Other researchers namely Sianturi and Gultom (2016) stated that students who still had learning difficulties in Biology material were quite high at $61.15 \%$. And from the analysis of data obtained through questionnaires, the factors that most influence learning difficulties are the subject matter factors which are $75.55 \%$. In other biological materials such as genetics it is referred to as material that is difficult for students to learn even by their own teachers [4]. In the study explained internal factors are the cause of learning difficulties, namely interest, while the external factor is the teacher.

From some of the explanations above, it turns out there are still student learning difficulties in biological material and these difficulties come from internal and external factors of students. Factors that cause the existence of learning difficulties in students may also be because the teacher himself does not know that his students have difficulty learning or the teacher himself has no knowledge of learning difficulties. Teachers who teach in the classroom do not have knowledge about learning difficulties so they do not understand that their students have difficulties. [5]

Research on learning difficulties is very important so that teachers are more aware of the learning difficulties experienced by students in particular and improve students' critical thinking skills in human digestive system material so that later learning outcomes can be better. Wardana stated that learning activities should prepare students who have the ability to solve problems, be critical, and be creative, in conditions that are national, regional, and global. From the description above, it is necessary to do a study of the analysis of learning difficulties and the ability to solve problems with students' cognitive abilities.

\section{MATERIALS \& Methods}

\subsection{Research Design}

This research is a type of quantitative descriptive research or survey method. This research was conducted at Sibolga City Public High School in September - November 2017. The population in this study was all students of Class XI IPA Sibolga City High School.

\subsection{Study Samples}

The population in this study were all students of Class XI IPA High School in Sibolga City as many as 522 people. The sampling technique used is probability sampling, namely by simple random sampling (Sugiyono, 2001). Sampling is done in a random manner without regard to the strata that exist in that population. Samples in this study are students who have incomplete scores on digestive system material (values below 75) from each school, namely 3 schools where each school is taken 2 classes / school as a research sample. The sample in this study was 196 students.

\subsection{Instruments}

Questionnaires are non-test instruments in the form of a list of questions or statements that must be answered by the person who is the subject of the research. In this case a statement with closed nature is used which provides alternative answers to measure students' opinions about the learning difficulties experienced. The assessment sheet for questionnaires uses a Likert scale with five alternative answers that are always, often, sometimes and never. To obtain quantitative data, then each alternative answer is given a score that is always $=4$, often $=3$, sometimes - sometimes $=2$, and never $=1$ [6] To find out the ability to solve questions with the cognitive domain of students used tests are arranged with reference to the form form Cornell Critical Thinking Test Series by Ennis et al. This test contains cognitive, affective or konasi information in the form of deduced thinking with a multiple choice test. The data collected in this study is cognitive ability data in digestive system material.

\section{RESULTS \& DISCUSSION}

\subsection{Result}

During learning, student learning outcomes are obtained by using tests and giving scores on the answers given by students to the digestive system material with predetermined criteria. Recapitulation 
Investigation on the Current Teaching Situation of English Picture Books for Preschool Children in Zhoushan and Its Commercial Prospects

of student learning outcomes in high school throughout Sibolga City in the learning process can be described in table 1:

Table1. Value of Class XI High School Student Learning Outcomes

\begin{tabular}{|r|l|l|l|}
\hline No & \multicolumn{1}{|c|}{ School Name } & \multicolumn{1}{c|}{$\overline{\boldsymbol{X}}$ Value } & \multicolumn{1}{c|}{ Criteria } \\
\hline 1 & SMA 1 MIA 6 & 55 & Low \\
\hline 2 & SMA 1 MIA 5 & 52 & Low \\
\hline 3 & SMA 2 MIA 3 & 38 & Low \\
\hline 4 & SMA 2 MIA 4 & 42 & Low \\
\hline 5 & SMA 3 MIA 3 & 58 & Low \\
\hline 6 & SMA 3 MIA 4 & 49 & Low \\
\hline Jumlah rata-rata & 49 & Low \\
\hline
\end{tabular}

Based on the table above, it can be seen the average learning outcomes of high school students throughout Sibolga City on human digestive system material in the low category. The highest value is equal to 58 in the 3 MIA 3 high school, while the lowest value is 38 in the 3 MIA 2 high school with low criteria. So from all the total average value of student learning outcomes shows there are still learning difficulties in the digestive system material. The low value of student learning outcomes is caused by a lack of interest and student learning motivation in attending the lesson, teachers in teaching and learning activities do not use innovative media and teaching aids, explanation of subject matter is more teacher-centered so that students' activeness is not created.

Factors that cause low student learning outcomes consist of two factors, namely internal factors originating from oneself and external factors originating from outside the student itself, including internal factors such as fatigue factors consisting of health / calmness and psychological factors consisting of interests, talents, motivation and concentration. The external factors include family factors which consist of the way parents educate children, relationships between families, home atmosphere and school factors consist of teaching / relation methods with teachers and community factors which consist of mass media and friends. So that students experience learning difficulties. Overall, the results of the assessment of the learning difficulties of students in Sibolga City can be known in detail the percentage of each school in the analysis table of the learning difficulties of high school students in Sibolga City in table 2:

Table2. Level of Student Learning Difficulties in Digestive System Material

\begin{tabular}{|l|l|l|l|}
\hline \multicolumn{1}{|c|}{ No. } & \multicolumn{1}{|c|}{ School Name } & \multicolumn{1}{c|}{ Level of Learning Difficulties(\%) } & \multicolumn{1}{c|}{ Criteria } \\
\hline 1. & SMA 1 MIA 5 & 60,06 & Middle \\
\hline 2, & SMA 2 MIA 3 & 60,24 & Middle \\
\hline 3. & SMA 3 MIA 3 & 60 & Middle \\
\hline 4. & SMA 1 MIA 6 & 59,66 & Middle \\
\hline 5. & SMA 3 MIA 4 & 54,64 & Middle \\
\hline 6. & SMA 2 MIA 4 & 54,48 & Middle \\
\hline & Rata-rata & 58,18 & Middle \\
\hline
\end{tabular}

Based on the recapitulation data above from all indicators of student learning difficulties, the highest average value was found in the Senior High School 2 MIA 3 of $60.24 \%$. The lowest average value of all indicators of learning difficulties is in the the Senior High School 2 MIA 4 school at $54.48 \%$ with the criteria being moderate. This value is the result of calculating the average value of each school using indicators of learning difficulties. These results indicate that the level of learning difficulties of students in MIA schools in Sibolga City is still in the moderate category. This indicates that there is still a need for improvement in the learning process through improving learning models, supporting facilities and infrastructure in using learning media.

Based on the recapitulation data above from all indicators of student learning difficulties, the highest average value was found in the the Senior High School 2 MIA 3 of $60.24 \%$. The lowest average value of all indicators of learning difficulties is in the Senior High School 2 MIA 4 at 54.48\% with the criteria being moderate. This value is the result of calculating the average value of each school using indicators of learning difficulties. These results indicate that the level of learning difficulties of students in MIA schools in Sibolga City is still in the moderate category. This indicates that there is still a need for improvement in the learning process through improving learning models, supporting 
Investigation on the Current Teaching Situation of English Picture Books for Preschool Children in Zhoushan and Its Commercial Prospects

facilities and infrastructure in using learning media. The results of the questionnaire data analysis on Biology learning difficulties in the digestive system in the Senior High School I MIA 5 can be seen in table 3:

Table3. Factors Affecting Learning Difficulties in the digestive system material

\begin{tabular}{|l|l|l|l|}
\hline \multicolumn{1}{|c|}{ No. } & \multicolumn{1}{|c|}{ Indicator } & \multicolumn{1}{|c|}{ Percentage (\%) } & \multicolumn{1}{c|}{ Criteria } \\
\hline 1. & Interest & $61 \%$ & Middle \\
\hline 2. & Motivation & $64 \%$ & High \\
\hline 3. & Talent & $60 \%$ & Middle \\
\hline 4. & Teacher Quality & $57,22 \%$ & Middle \\
\hline 5. & Facility and Infrastructure & $57,81 \%$ & Middle \\
\hline
\end{tabular}

The highest indicator is in the motivation indicator with an average of $64 \%$ with high criteria. Parents and teachers do not motivate students to study at home, making students less enthusiastic in learning because they do not get support from parents and teachers. In addition, internal factors that exist in students are intellectual ability factors, affective factors such as feelings, interests, motivation, maturity for learning, learning habits, ability to remember and the ability of sensory devices in seeing and hearing.

To create an atmosphere that fosters passion for learning, increases student prestige, it is necessary to organize a good learning process. To achieve a good learning process, students should be able to recognize the ability to solve problems with their own cognitive domain to create a good learning activity atmosphere. The teacher only creates an atmosphere that can encourage the emergence of student learning motivation. In achieving the learning process refers to several principles, namely, student-centered, learning by doing, developing, social treatment, developing problem solving skills, developing students' creativity, developing the ability to use science and technology, lifelong learning, a combination of competition, cooperation and solidarity.

The results of interviews with teachers there are external and internal factors that affect student learning difficulties so that achievement is low. Students are less able to master the digestive system material within a predetermined time limit because there are certain factors that influence it, these factors are partly due to students' lack of knowledge and certain basic skills. Basic knowledge and skills generally revolve around reading, writing, and counting. As a result of these weaknesses, students will always have difficulty learning other knowledge, so that the achievements they get are low and even fail to achieve success in school, if there is no effort to improve it. Broadly speaking, the factors that cause the emergence of learning difficulties consist of two kinds, namely internal factors and external factors. Internal factors faced are psychological, namely intelligence, talent, interest, motivation, and mental health while external factors, namely: factors family: how to educate parents or the guidance of parents and school factors: teachers who do not have skills in trying to diagnose student learning difficulties and learning difficulties caused by teacher teaching methods and tool factors, because without the tools, especially for practical subjects, will lead to difficulty learning. Because of the difficulty of the tool, the teacher tends to use the lecture method which can lead to student passivity. Thus, it can be concluded that the causes of learning difficulties can be individual causes or complex causes.

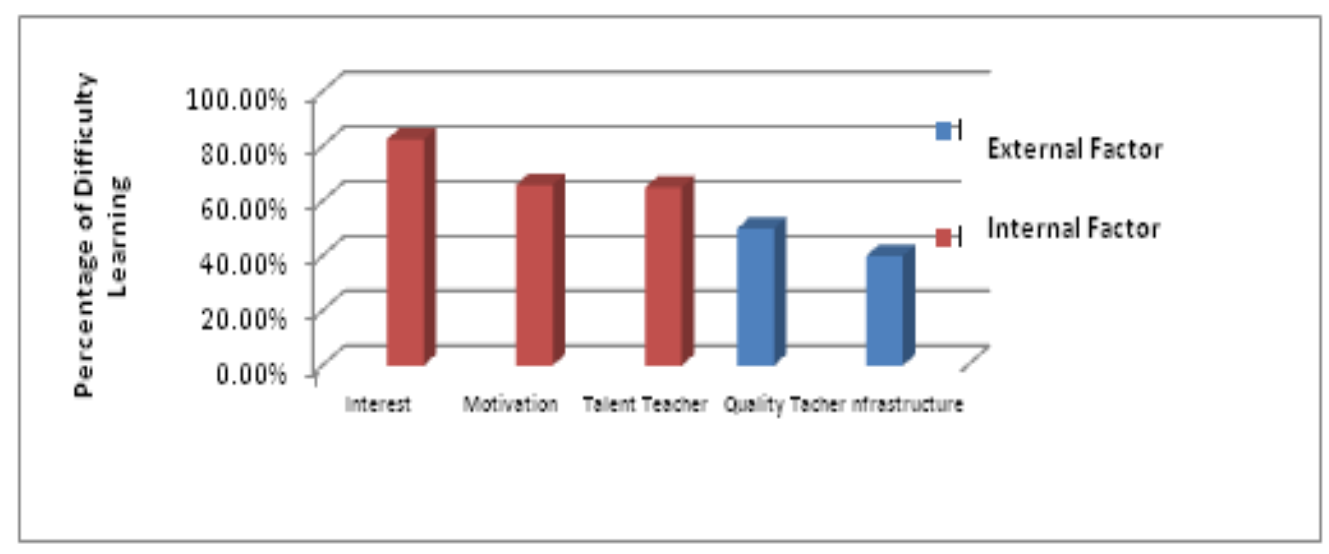

Figure1. External and Internal Factors Affecting Student Learning Difficulties 
Based on the results of data analysis that has been done, each student in principle must have the right to get the opportunity to achieve learning outcomes that are satisfactory. But from everyday reality it is clear that students have differences in terms of intellectual abilities, physical abilities, family background, habits and learning approaches that are sometimes very striking between a student and other students. In general, it is only shown to students with average abilities, so students who are more capable or who are less capable are neglected.

Student learning outcomes $<75 \%$ of the ideal average and included in the low category. This is because motivation, interests and abilities obtained by students after the learning process takes place on low digestive system material so that it does not optimally provide changes in behavior both students' knowledge, understanding, attitudes and skills become better than before. In addition, this learning outcome is one indicator of the learning process

\subsection{Discussion}

One indicator of whether or not a learning process is achieved is to look at the learning outcomes achieved by students. In line with Slameto (2003: 54), said that "the factors that influence learning and learning outcomes are many types, but can be classified into only two groups, namely internal factors and external factors. Internal factors are factors that exist in individuals who are learning, while external factors are factors that exist outside the individual. Internal factors are divided into three factors, namely: physical factors, psychological factors, and fatigue factors. While the extreme factors are divided into three factors, namely: family factors which include, the way parents educate, relations between family members, home atmosphere, family economic conditions, understanding of parents, cultural background. School factors include teaching methods, curriculum, teacher relations with students, student relations with students, school discipline, learning tools, school time, standardized learning above size, building conditions, learning methods, homework. Community factors which include the activities of students in the community, mass media, associates, forms of community life.

From several factors that influence student learning above, it can be said that the success of a student in learning is strongly supported from every aspect of life in the scope of students. In physical education desperately need support and enthusiasm from teachers, parents, and also the community as a trigger for students' interest in physical education so that students feel happy in attending physical education which is expected to have a proud achievement

Students who are "out of the average" (very smart and very stupid) do not have adequate opportunities to develop according to their capacity. This gives rise to learning difficulties in Sibolga City High School, which not only affects average students, but also those with low ability and high ability. From the results of the research and data analysis, the average learning difficulties of high school 1 MIA students at $60.06 \%$ are included in the medium category with motivational indicators. It can be seen that students lack motivation from parents and teachers to encourage good student learning abilities. The next indicator of students' interest with an average of $64 \%$ with moderate criteria, this is due to the learning model that has not been able to be fully followed by students, and the teacher's ability to explain has not been able to attract students. In line with the research of Kim and Thomson (2013), it was shown that learning difficulties were given because the teaching method was not as intensive as the conventional method (lecture), with the method being less enthusiastic in attending the lesson. These conditions have an impact on the low learning outcomes. In addition, learning material is still considered abstract and difficult to understand, less interesting and meaningful (Arifuddin, 2014). In line with the opinion of Sugihartono (2012), learning difficulties seen in students are characterized by the existence of low or under-set learning achievements, as well as the opinion of Hamalik (2005), learning difficulties have various forms of real difficulties in listening activities, conversations, reading, writing, reasoning, and counting. Students' interest in learning about digestive system material is influenced by internal factors that exist in students that are affective factors such as feelings, interests, learning, learning habits, ability to remember and the ability of sensory devices to see and hear. The lowest indicator is in teacher quality indicators with an average of $54.5 \%$ with moderate criteria. Teachers who teach with the lecture method make students quickly bored in learning. This shows that it is very important to use learning models in delivering material so that it does not cause student saturation. 
This is in line with the opinion of Syamsudin (2002) that the inadequate professional abilities and personality of teachers can cause learning difficulties for students and can reduce students' interest in learning. Furthermore, indicators of student learning talent in the digestive system material are influenced by internal factors that exist in the student's self is an affective factor. This indicates that interest must be formed from feelings of joy and pleasure, but there are still a number of schools that have a low category of this indicator, namely high school 2 MIA 3. Furthermore, the lowest indicator is in the indicator of infrastructure with an average of 58,3\% with medium criteria. The results of the analysis show that the facilities and infrastructure greatly affect the ability of students to learn. The role of facilities and infrastructure is very important in supporting the quality of student learning. Given the importance of infrastructure in learning activities, students, teachers and schools will be directly related. Students will be more helped by the support of learning infrastructure. Not all students have a good level of intelligence so that the use of learning infrastructure will help students, especially those who have weaknesses in participating in learning activities.

The level of understanding obtained by students is greater because students are involved directly in finding answers to problems and immediately apply them through data collection and then analyzed so that the learning process is more effective and efficient. This Collaborative Based Inquiry learning model is very good for students who have high curiosity because this learning model makes students more active and leads directly to the essence of the material. This is in accordance with Usman et al. (1993) about the benefits of Inquiry learning models, among others: 1. Developing abilities and skills in solving problems and making decisions objectively and independently, 2. Developing critical and analytical thinking skills, 3 . Developing curiosity and objective thinking both individually and in groups.

In accordance with Maasaki's (2012) expression which suggests that the notion of collaboration is collaborating with other students to solve a problem, students respect each other's existence and in an organized manner they carry out an activity by combining the mind that was felt alien to itself. Besides that the foundation of constructivism learning theory used is Tory Vigotsky who emphasizes social nature and learning. Vigotsky argues that students learn through interaction with adults or peers who are more capable (Slavin, 2000). The main implication in learning physics based on Vigotsky's theory is that the class arrangement takes the form of cooperative learning between students, so that students can interact around difficult tasks and bring together effective strategies for Critical Thinking strategies in each student. The ability to think critically requires a strong effort to examine every belief and knowledge or asumen based on conclusions. Furthermore, according to the opinion (Hendra, 2013) critical thinkers systematically analyze information using an organized approach based on logic to test the constraints of information, not just take for granted how to teach something only because so far how to do it and do not assume a true statement just because someone else justifies it. From some of the opinions above it can be concluded that critical thinking skills can be developed by training children to see, and overcoming simple concrete problems that are around them. This can be done by integrating them in various subjects allows for the development of that thinking.

Someone who has the ability to solve problems with the cognitive realm can be seen from the attitude of accepting new ideas, being able to think through different ways to a problem. Students who are able to solve questions with the cognitive domain if they have difficulty in learning will think about how to solve the problem based on the facts that occur. The ability of a student in the ability to solve questions with cognitive domains is different. This difference can be caused by differences in intelligence and how to capture a problem in the learning process which is then analyzed. The results of this study prove that there is a strong correlation between students' learning difficulties and the ability to solve questions with the cognitive domain of students, namely the correlation coefficient of 0.700. This is in line with the opinion of Wardana (2008) stating that learning activities should prepare students who have the ability to solve problems, critical, and creative, in conditions that are national, regional, and global.

\section{CONCLUSION}

Based On This Study The Learning Outcomes of high school students throughout Sibolga City on human digestive system material in the low category. Students in High School 1 in Sibolga City had learning difficulties due to external and internal factors. Level of ability to solve questions with the 
cognitive domain of Sibolga City High School students 3 schools (50) students who had the ability to solve problems with a very good cognitive domain, MIA 1 High School 6 (5.5), Senior High School 1 MIA 5 (2.85), the ideal average ability to solve questions with the cognitive domain of students is sufficient. Students' interest in learning about digestive system material is influenced by internal factors that exist in students that are affective factors such as feelings, interests, learning, learning habits, ability to remember and the ability of sensory devices to see and hear. The lowest indicator is in teacher quality indicators with an average of $54.5 \%$ with moderate criteria.

\section{REFERENCES}

[1] Djamarah, B.S.2011. Learning Psychology. Jakarta : Rineka Cipta

[2] (OECD) Organization for Economic Coperation Development, 2016. Eutropication of Waters. OECD Publications Office. Paris

[3] Huda, M. 2013. Teaching and Learning Models. Yogyakarta: Pustaka Pelajar.

[4] Hidayatussaadah R, Hidayati S, Umniyatie S. 2016. Identification of Learning Difficulties of Students in Archaebacteria and Eubacteria in Muntilan 1 High School. Journal of Biology Education. Vol. 5. No.7, 2016

[5] Komalasari. K., 2014. Contextual Learning: Concepts and Applications. Bandung: PT Refika Aditama 2014

[6] Riduan, 2010. Statistics. Bandung: Alfabeta

\section{AUTHORS' BIOGRAPHY}

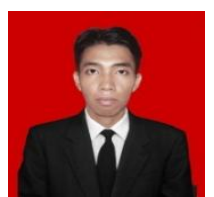

Rahmad Agus Sinaga, S.Pd, is a Biology Education Postgraduate student at Postgraduate Program of Universitas Negeri Medan (State University of Medan), Medan, North Sumatera, Post code 20221, Indonesia.

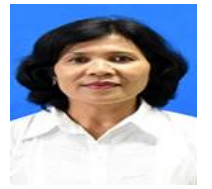

Dr. Melva Silitonga, M.Si, is a Lecturer at Graduate and Postgraduate Program of Universitas Negeri Medan (State University of Medan), Medan, North Sumatera, Post code 20221, Indonesia.

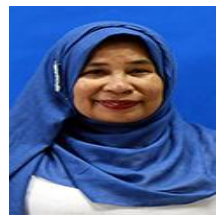

Dr. Martina Restuati, M.Si, is a Lecturer at Graduate and Postgraduate Program of Universitas Negeri Medan (State University of Medan), Medan, North Sumatera, Post code 20221, Indonesia.

Citation: Rahmad Agus Sinaga, et.al. "Analysis of Student Learning Difficulties in the Material of Digestive Systems in Sibolga City High Schools". International Journal of Humanities Social Sciences and Education (IJHSSE), vol. 6, no.5, 2019, pp. 83-89. doi: http://dx.doi.org/10.20431/2349-0381.0605008.

Copyright: (C) 2019 Authors. This is an open-access article distributed under the terms of the Creative Commons Attribution License, which permits unrestricted use, distribution, and reproduction in any medium, provided the original author and source are credited. 